Плюта Олена Павлівна

ORCID ID 0000-0001-8515-8218

аспірантка,

Київський національний університет

культури і мистещтвв,

Київ, Украӥна

plyuta-olena@ukr.net

\title{
КУХНЯ ЯК РЕПРЕЗЕНТАНТ ГАСТРОНОМІЧНОЇ КУЛЬТУРИ В СУЧАСНОМУ СУСПІЛЬСТВІ
}

Мета даної статті - 3'ясування особливостей трансформації кухні як складової гастрономічної культури сучасного суспільства. Методологія дослідження - робота грунтується на методології комплексного аналізу, що передбачає звернення до методів різних наук (культурології, філософії, історії) для найбільш глибшого проникнення в сутність досліджуваного явища й отримання максимально повного знання про нього. Новизна дослідження полягає в тому, що його результати вводять у науковий обіг нове знання про сферу харчування, змушують по-новому поглянути на співвідношення традиційного та інноваційного в культурогенезі, на процеси самоідентифікації, що $є$ важливим для прояснення загальних питань теорії та історії культури. Результати i висновки. Процеси американізації та вестернізації харчування, лідируюча роль фаст-фуду є неминучими в сучасному суспільстві. 
Глобалізація 3 iï новими моделями просторової організації соціокультурної реальності зробила затребуваними одні форми гастрономічної культури та деактуалізувала інші. У результаті індустріалізації сфери харчування, кулінарна культура сучасного міста не може представляти будь-яку одну культурну традицію. Незважаючи на можливість існування кулінарної символіки, що представляє даний простір, місто зазвичай презентує своєрідний кулінарний «мікс» 3 різних національних кухонь і стилів харчування. Особливим статусом володіють публічні місця споживання їжі, які, функціонуючи в найрізноманітніших варіантах, надають додаткового значення самому процесу споживання їжі, що стає способом утвердження себе в очах іншого. Масова свідомість за допомогою ЗМІ та реклами наповнюється інтересом до метафізичної сторони їжі й харчування, а часом й екзистенціального їх змісту, фіксуючи взаємозв'язок їжі та ії̈ вплив на внутрішній світ людини і ії душевний стан. Дане дослідження не вичерпує усіх аспектів дослідження: подальшого вивчення потребують питання їжі як фрагмента національної картини світу, культурної уніфікації в сфері харчування, структури, функцій та форм репрезентації гастрономічної культури українців.

Ключові слова: культура, кухня, гастрономія, гастрономічна культура, харчові практики, споживання, їжа.

Плюта Елена Павловна, аспирантка, Киевский национальный университет культуры и искусств, Киев, Украина 
Кухня как репрезентант гастрономической культуры современного общества

Цель данной статьи - выяснение особенностей трансформации кухни как составляющей гастрономической культуры современного общества. Методология исследования работа основывается на методологии комплексного анализа, предполагающего обращение к методам различных наук (культурологии, философии, истории) с целью более глубокого проникновения в сущность изучаемого явления и получения максимально полного знания о нем. Новизна исследования заключается в том, что его результаты вводят в научный оборот новое знание о сфере питания, заставляют по-новому взглянуть на соотношение традиционного и инновационного в культурогенезе, на процессы самоидентификации, что является важным для прояснения общих вопросов теории и истории культуры. Результаты и выводы. Процессы американизации и вестернизации питания, лидирующая роль фаст-фуда неизбежны в современном обществе. Глобализация с ее новыми моделями пространственной организации социокультурной реальности сделала востребованными одни формы гастрономической культуры и деактуализировала другие. Вследствие индустриализации сферы питания кулинарная культура современного города не может представлять какую-либо одну культурную традицию- город обычно представляет своеобразный кулинарный «микс» из разных национальных кухонь и стилей питания. Особым статусом обладают публичные места потребления пищи, которые, 
функционируя в самых разнообразных вариантах, предоставляют дополнительное значение самому процессу потребления пищи, что становится способом утверждения себя в глазах другого. Массовое сознание с помощью СМИ и рекламы наполняется интересом к метафизической стороне пищи и питания, а порой и экзистенциального их содержания, фиксируя взаимосвязь пищи и ее влияние на внутренний мир человека и его душевное состояние. Данное исследование не исчерпывает всех аспектов исследования: дальнейшего изучения требуют вопросы пищи как фрагмента национальной картины мира, культурной унификации в сфере питания, структуры, функций и форм репрезентации гастрономической культуры в Украине.

Ключевые слова: культура, кухня, гастрономия, гастрономическая культура, пищевые практики, потребление, еда.

Pliuta Olena, postgraduate, Kyiv National University of Culture and Arts, Kyiv, Ukraine

Cuisine as a representative of the gastronomic culture of modern society

The purpose of the article is to elucidate the features of the transformation of cuisine as a component of the gastronomic culture of modern society. The research methodology was based on the methodology of complex analysis, involving the use of methods of various sciences (culturology, philosophy, history) in order to penetrate deeper into the essence of the studied phenomenon and to obtain the fullest possible knowledge of it. The scientific novelty of the research 
lies in the fact that its results introduce new knowledge about the field of nutrition into scientific practice, give grounds for taking a fresh look at the correlation between the traditional and the innovative in cultural genesis, the processes of self-identification, which is important for clarifying general questions of theory and the history of culture. Results and conclusions. The processes of Americanization and westernization of nutrition, and the leading role of fast food are inevitable in modern society. Globalization, with its new models of the spatial organization of socio-cultural reality, has made some forms of gastronomic culture popular and obsoleted others. Due to the industrialization of the food industry, the culinary culture of the modern city cannot represent any one cultural tradition. Although culinary symbols representing the concerned space may exist, the city usually presents a kind of culinary mix of different national cuisines and food styles. A special status is enjoyed by public places of food consumption, which, functioning in a variety of options, attach additional value to the very process of food consumption, which becomes a way of asserting oneself in the eyes of another. Mass consciousness with the help of the media and advertising is filled with interest in the metaphysical side of food and nutrition, and sometimes even their existential content, setting the interrelationship between food and its influence on the inner world of man and his state of mind. This study does not exhaust all aspects of the research: issues of food as a fragment of the national picture of the world, cultural unification in the field of nutrition, structure, functions and forms of representation of gastronomic culture in Ukraine require further investigation. 
Key words: culture, cuisine, gastronomy, gastronomic culture, food practices, consumption, food.

Вступ. Вивчення харчування людини - тема надзвичайно велика й різнопланова. Вона об'єднує медичні, психологічні, морфологічні, фізіологічні, біохімічні дослідження та етнографічні спостереження, фольклор, аналіз широкого спектра археологічних джерел і письмових свідчень. Окреме коло проблем пов'язане 3 вивченням господарської діяльності, торгівлі та економічного ладу. У науковому обігу вивчено два аспекти харчування: споживання (в межах фізіології й дієтології) та виробництво (в межах економіки, бізнесу й технічних наук). Але їжа - це ще й один з найважливіших чинників соціального життя людини, компонент етнічної, релігійної, соціальної ідентичності, що відображає цінності певної спільноти. Невипадково, симптоматичною ознакою сучасної культури є якісна зміна ставлення до харчування, особливо до тих перетворень, що відбуваються в цій сфері під впливом процесів глобалізації. У такому аспекті їжа, особливості харчування, загалом гастрономічна культура та іï складова - кухня, досліджені вкрай недостатньо.

У гуманітаристиці проблематика «їжа й культура» розроблялася переважно етнографами та філологами. Так, етнографічний підхід до дослідження їжі пов'язаний, насамперед, з дослідженням функцій та семантики їжі в традиційних суспільствах, як це властиво для праць $\quad$ I. Ф. Дмитрук «Гуцульщина в етнографічних дослідженнях кінця XIX - початку 
XXI ст.». Дослідницею розкрито рівень вивчення в етнографічних працях матеріальної й духовної культури гуцулів, теорії їх походження, територіальні межі проживання, декоративноприкладне мистецтво та народну творчість. Філологічні ж розвідки концентруються навколо семантики харчових образів у художніх творах та етнолінгвістичних досліджень традиційної їжі. Так, естетична активність образів їжі й напоїв у творах Михайла Булгакова досліджена в праці «Естетична активність образів їжі і пиття в творах Михайла Булгакова» В. В. Хіміч.

На межі лінгвістики, фольклористики й етнографії здійснюються етнолінгвістичні дослідження традиційної їжі, серед яких варто виокремити працю «Слов'янська етнолінгвістика: питання теорії» М. I. Толстого та С. М. Толстої, присвячену теоретичним питанням слов'янської етнолінгвістики, іiї основним поняттям і методам, iї співвідношенню 3 іншими гуманітарними дисциплінами - мовознавством, фольклористикою, етнографією та ін.

Л.Ф. Артюх, відомим українським етнологом, провідним знавцем народної кухні й харчування, досліджено різні аспекти народної їжі. Зокрема у монографії «Українська народна кулінарія (історично-етнографічне дослідження)», науковцем висвітлено особливості їжі й харчування українського народу як елемента матеріальної культури, а також подано етнографічний опис i класифікацію повсякденної та святкової обрядової їжі українського селянства доби капіталізму, проаналізовано іï соціальну функцію. В іншій своїй праці «Звичаї українців у народному календарі» (Київ, 
2012) дослідниця у 23 розділах, присвячених святам календарного року українського народу - від Святвечора до дня святого Андрія, подає рецепти традиційних страв національної кухні.

Проблема їжі й харчування тією чи іншою мірою висвітлюється також дослідниками українського побуту В. К. Борисенко [1], В. І. Наулко [9], О. М. Кравець [5], О. Ф. Кувеньова [6], В. А. Маланчук [8], які розглядали ці питання в різних контекстах. С. А. Яценко у статті «Традиційна народна їжа як предмет етнографічного дослідження» [12] аналізує праці вчених, які досліджують українські страви й традиції харчування українців. М. В. Жовнірова та Р. В. Дьяченко [3], досліджуючи питання харчування як елемента традиційно-побутової культури українців, звертають, зокрема, увагу й на тенденцію звуження якісного різноманіття повсякденного меню за рахунок недостатнього використання народних традицій українців у харчуванні. Ю.В.Ліпєц розкриває традиції харчування в українській культурі [7]. А. В. Волковою в статті «Науковоетнографічне дослідження особливостей технології страв української національної кухні» [2] досліджено особливості технології продукції української національної кухні, обумовлених історичними та етнографічними детермінантами.

Однією 3 перших публіцистичних розвідок у напрямі осмислення системи харчування сучасних українців у процесах постійно зростаючої соціальної напруги та інтенсифікації ритму повсякденних відносин, $\epsilon$ праця національне харчування: минуле i майбутнє. Уроки здоров'я» 
(Дніпропетровськ, 2009), в якій дослідник на основі соціальнодиференційованих характеристик звертає увагу на особливості національної системи харчування та найбільш небезпечні модуси іiі трансформації. Систематизовані дані про витоки української кухні містяться в праці відомого знавця кулінарії В.В.Похльобкіна «Національні кухні наших народів», уперше виданій в 1978 р.

Спробою цілісного культурологічного аналізу сфери харчування є праці таких сучасних зарубіжних дослідників, як історик-медієвіст, фахівець з історії харчування М. Монтанарі, Ж.Ф. Ревель. Так, М. Монтанарі, викладач єдиного в світі Університету гастрономічних наук, у своїй книзі «Голод і достаток. Історія харчування в Європі» простежує еволюцію традицій харчування в Європі з ІІІ по XX ст. Французький філософ i письменник Ж.-Ф. Ревель у праці «Кухня і культура: Літературна історія гастрономічних смаків від Античності до наших днів» описує гастрономічні зміни від Афін часів Перикла до нової кухні через імператорський Рим, європейське Середньовіччя, відкриття Нового Світу, звідки прийшли невідомі до тих пір продукти, через Італію Медичі, Францію Людовика XIV, не забуваючи про значення національної кухні й народних традицій.

Чи не $є$ єдиним грунтовним дослідженням, суміжним 3 проблематикою кухні, є докторська дисертація В.В.Ніколенка «Гастрономічні детермінанти суспільного життя: соціологічний вимір», в якій обгрунтовано, з одного боку, зв'язок між гастрономічним виміром суспільного життя, а 3 іншого- 
соціальними процесами та відносинами як в ретроспективному контексті, так і сучасному.

Незважаючи на значну кількість різнорідних досліджень сфери харчування, такі проблеми все ж залишаються за межами культурологічного розгляду. Перш за все, потребує уваги питання трансформації кухні як форми репрезентації гастрономічної культури під впливом процесів глобалізації, зокрема американізації, вестернізації сфери харчування.

Мета статті - 3'ясування особливостей трансформації кухні як складової гастрономічної культури сучасного суспільства.

Виклад основного матеріалу. Національна кухня - це харчові уподобання нації, що знаходять відображення в споживанні певних страв і так званих спеціалітетів, тобто продуктів специфічних для конкретної місцевості. Ці уподобання є доволі стійкими і поділяються усіма носіями даної культури. Національна кухня часто репрезентується як споконвічна i зближується за своїми характеристиками з тим, що називають народною кухнею, проте ця тотожність не відповідає дійсності. Народна або селянська кухня (вона ж регіональна) має локальний характер - вона грунтується на локальних доступних продуктах і простих способах їх обробки, а транслюється за допомогою усної традиції 3 покоління в покоління i, незважаючи на деяку спільність прийомів, $\epsilon$ сукупністю окремих сімейних традицій. Попри те, що національна кухня розглядається як утворення, що звертається до традиції, фактично вона має справу 3 актуальним станом гастрономічної культури. 
Нині гастрономічна культура, зокрема культура споживанні їжі, змінюється під впливом процесів глобалізації. Головною ознакою останньої, що грунтується на культурній відкритості країн i народів, у харчових практиках стала поява так званої «наднаціональної» або уніфікованої форми їжі, під якою розуміються збільшувані швидкісні потоки продуктів харчування, які долають кордони країн і континентів і виходять за межі їх початкового місця виникнення (піца, суші, гамбургер, курячі ніжки тощо). Вся ця «наднаціональна» їжа знаходить все більшу кількість прихильників і споживачів, i не лише впливає на культурнолокальні смаки, а й формує, власне, наднаціональний смак. Така їжа має безсумнівні переваги: дешевизна i, так би мовити, «толерантність» (тобто терпимість до «чужої» їжі); затребуваність відповідно до сформованих смаків; висока калорійність; співпричетність споживача до відомих брендів. Проте, крім цих переваг, є й недоліки: наприклад, «кока-колонізація» ${ }^{1}$, яка витісняє традиційну та сезонну їжу, зокрема, соління, які мають самостійну культурну та харчову цінність; проблема відповідності медичним стандартам взагалі і фізіологічній сприйнятливості організмів конкретних етносів; складність диференціації їжі за наднаціональним і національним принципом; виникнення так званої «гібридної» їжі (включає поєднання двох і більше елементів харчування, які відносяться до різних культур світу, наприклад, «японські суші» або «швейцарський сир», вироблені в Україні).

\footnotetext{
1 Словосполучення, що використовується для характеристики нераціонального способу життя багатьох сучасних людей: низька фізична активність у поєднанні 3 прийомом великої кількості їжі з високим вмістом жирів і рафінованих вуглеводів.
} 
«Наднаціональна» їжа, насамперед, представляє «третю культуру», яка неоднозначно впливає на характер ціннісних орієнтацій людей. 3 одного боку, завдяки їй багато людей отримують можливість пізнати й інтерпретувати культурно іншу, «чужу», їжу. 3 іншого, вона може спровокувати ті чи інші культурно обумовлені соціальні колізії. Йдеться про те, що «наднаціональна» (або, точніше, «гібридна» їжа) може містити значну кількість інгредієнтів з різних куточків світу, які є цілком функціональними в межах традиційних харчових практик певної країни, але не відповідають повною мірою вимогам харчування або культурі в інших країнах (наприклад, «гібридна» їжа, зокрема, не відповідає принципам роздільного харчування, дієті віруючих певних конфесій тощо).

На зміну характеру і змісту їжі суттєво вплинули такі нові типи раціональності, як рефлексивність, макдональдизація та ін. Так, на переконання американського соціолога, прибічника теорії раціональності Дж. Рітцера, завдяки макдональдизації, процесу, «під час якого принципи роботи ресторану швидкого обслуговування починають визначати все більшу й більшу кількість сфер американського суспільства, як і решти світу» [10], зародилося й утвердилося принципово нове швидке харчування, реалізоване компаніями «Макдональдс», «Бургер Кінг», «Піца Хат», «Курчата 3 Кентуккі» та ін. Аналіз причин інтенсивного поширення принципів роботи ресторанів швидкого обслуговування дає соціологу підстави переконатися в тому, що їх (принципів) 
сукупність $є$ достатньо адекватною сучасним мікросоціальним практикам людей.

Практично у всьому світі швидке харчування (або фаст-фуд) знаходить національно-локальні форми. У нашій країні- це, наприклад, крім «Макдональдс», мережі національних ресторанів швидкого харчування «Швидко», «Пузата хата», «Здоровенькі були», де подаються млинці, салати та ін., і можна за 5-10 хвилин перекусити. Але всі вони грунтуються на загальних принципах макдональдизованої раціональності: ефективність, калькульованість, передбачуваність i контроль [10]. Так, ефективність, за Дж. Рітцером, полягає у створенні сприятливих умов швидкої їжі, абсолютно необхідних за сучасного динамізму життя як окремої людини, так і суспільства. Передусім, калькульованість акцентує кількісні параметри пропонованих товарів і послуг, що стосується розміру порцій та їх вартості, а також тимчасових витрат. При цьому кількість стала еквівалентом якості: швидка доставка, насамперед, означає хороша, якісна доставка. Аналогічно, більше - значить краще. Звідси слогани: з’їж (випий, купи) щось «подвійне», «потрійне» і тим самим заощадь. Передбачуваність має на увазі, що страви будуть однаковими незалежно від часу і місця, коли і де вони пропонуються. Контроль здійснюється за допомогою технологій, в яких відсутній (зведений до мінімуму), власне, людський чинник. Крім того, контролюється час, що витрачається на обслуговування клієнтів: обмежене меню, невеликий вибір, незручні жорсткі сидіння- все це змушує відвідувачів швидко їсти і йти. Отже, для сучасної людини в 
системі швидкого харчування є багато переваг. Разом 3 тим його сутнісним елементом, вважає Дж. Рітцер, є особлива ірраціональна раціональність, яка проявляється в новій формі відчуження у вигляді роботизації людських відносин [10]. Дегуманізується сам процес прийняття їжі: традиційно трапеза передбачала соціальну взаємодію людей, яку нині зведено до мінімуму, бо і відвідувачі, i працівники «Макдональдс» стають роботами великого конвеєра.

Такий уніфікований формат харчування як фаст-фуд виник спочатку як гастрономічна практика американської культури, але 3 часом він ознаменував «перемогу» над природним вмістом їжі в багатьох країнах світу, виявився символічною для глобалізованого світу їжею: у фаст-фуді культурний зміст вилучено, а його цивілізаційний формат виступає для сучасної людини, вимушеної жити в полікультурній та поліетнічній реальності, способом уникнути жахаючого зіткнення з іншим на тілесному рівні. Фастфуд як продукт харчової індустрії, в якій втрачена культура трапези на перевагу так званому перекусу, не можна оцінювати ні позитивно, ні негативно - але необхідно визнати факт: що саме фаст-фуд сьогодні став новою культурою їжі, яка «вписала» в себе базові коди тієї технократичної, урбаністичної, техноморфної реальності, в якій багато традиційних для людини проблем досягли свого апогею.

Пов’язані з поширенням фаст-фуду процеси американізації й вестернізації $^{2}$ харчування загрожують кухням традиційним

\footnotetext{
2 Американізація має на увазі швидку їжу, фаст-фуд як матеріальний субстрат цінностей американської культури і їх тілесне засвоєння за допомогою споживання такої їжі; вестернізація харчування означає процес засвоєння традиційною кухнею так званих цивілізованих форм їжі.
} 
культур, і це є проблемою для тих, чия ідентичність тісно пов'язана 3 вживанням в їжу саме національної їжі, тобто для представників невеликих культур 3 найбільш автентичною традиційністю. А. І. Козлов у дослідженні «Їжа людей» [4] зазначає, що традиційна їжа при зіткненні з їжею індустріалізованою зазнає поразки в силу кількох причин. Незважаючи на те, що кордони між їжею своєю і «чужою» у традиційної людини дуже міцні, при їх катастрофі, зокрема, здатність «чужої» знищити своє набагато вища, ніж у культури, що йде шляхом еволюції й активно взаємодіє з іншими. Індустріалізована їжа для людини, яка звикла залежати від природних циклів виробництва харчування, сприймається жахаюче чудовою - вона може довго зберігатися і бути готова до вживання; може мати додаткову цінність у вигляді упаковки, що використовується потім для інших цілей. Втрата гастрономічної автентичності призводить до швидкої втрати власної національної ідентичності - в цьому плані індустріалізована їжа $є$ потужною зброєю глобалізації: «Активне (в таких випадках навіть насильницька) впровадження нових продуктів, елементів кухні й культури харчування в цілому можна розцінювати як один з етапів асиміляції одного народу іншим» [4].

Криза національних систем харчування та їх потенційна готовність зникнути під тиском американізованого й вестернізованого харчування є серйозною проблемою, такою ж як і трансформація домашньої кухні, коли сімейна харчова політика моделюється рекламою продуктів харчування та економічними стратегіями, висунутими харчовою індустрією, і більш за все 
представленими у величезних супермаркетах економ-класу, популярних 3МІ тощо. Крім того, з'явилася принципово нова техніка, орієнтована на різноманітність кулінарних смаків мікрохвильові печі, скороварки, мультиварки, шашличниці, коптильні, кавоварки, міксери і ще безліч предметів. Невипадково, серед причин трансформації культури їжі називають також активну технізацію життя і все зростаючу опосередкованість звичних практик турботи-про-себе технічними засобами, «які, втручаючись у простір самостановлення людини, активно впливають на конструювання ії ідентичності» [11].

Мережі швидкого харчування типу Макдональдс є не єдиним аспектом глобалізації харчування. Їх тіснять конкуренти, які пропонують екзотичне меню, італійську, мексиканську, китайську, японську кухні, а також стиль фьюжн ${ }^{3}$. Не випадково, одна 3 яскравих постмодерністських метафор культури, що відображає фрагментований характер культурного успадкування,- це образ шведського столу. «Всеїдність» сучасної культури в прямому сенсі виражається в інтересі до різних традицій харчування, їх вільному відборі й поєднанні. Це відображається і в рекламі харчових продуктів, що експлуатує географічні та історичні образи, завдяки яким споживач відкриває для себе різноманітність світової культури і спадщини минулого.

Таким чином, новизна даного дослідження полягає в тому, що його результати, 3 одного боку, вводять в науковий обіг нове знання про сферу харчування, а з іншого - змушують по-новому

\footnotetext{
${ }^{3}$ Від англ. fusion - змішання, сплав, злиття; напрям в кулінарії, в якому в рівних частках змішуються технології і продукти географічно віддалених національних кухонь.
} 
поглянути на співвідношення традиційного та інноваційного в культурогенезі, на процеси самоідентифікації, що є важливим для прояснення загальних питань теорії та історії культури.

Висновки. Підсумовуючи вищевикладене, можна стверджувати, що процеси американізації та вестернізації харчування, лідируюча роль фаст-фуду, є не просто очевидними, а й неминучими в сучасному суспільстві. Глобалізація з їі новими моделями просторової організації соціокультурної реальності зробила затребуваними одні форми гастрономічної культури і деактуалізувала інші.

У результаті індустріалізації сфери харчування кулінарна культура сучасного міста не може представляти будь-яку одну культурну традицію. Незважаючи на можливість існування кулінарної символіки, що представляє даний простір, місто зазвичай презентує своєрідний кулінарний «мікс» 3 різних національних кухонь і стилів харчування. Особливим статусом володіють публічні місця споживання їжі, які, функціонуючи в найрізноманітніших варіантах, надають додаткового значення самому процесу споживання їжі, що стає способом утвердження себе в очах іншого. Більше того, масова свідомість за допомогою ЗМІ і реклами наповнюється інтересом до метафізичної сторони їжі й харчування, а часом й екзистенціального їх змісту, фіксувати

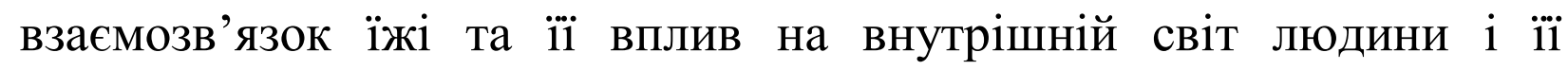
душевний стан.

Дане дослідження не вичерпує усіх аспектів дослідження: подальшого вивчення потребують питання їжі як фрагмента 
національної картини світу, культурної уніфікації в сфері харчування, структури, функцій та форм репрезентації гастрономічної культури українців.

\section{Список використаних джерел}

1. Борисенко М. Побут міських мешканців України в 30-х роках XX століття / М. Борисенко // Етнічна історія народів Європи. - 2008. - Вип. 24. - С. 12-18.

2. Волкова А. В. Науково-етнографічне дослідження особливостей технології страв української національної кухні / А. В. Волкова // Траектория науки : электрон. науч. журн. - Харків, 2015. - T. 1(1). - C. 4.1-4.8.

3. Жовнірова М. В. Їжа і харчування як елемент традиційнопобутової культури українців / М.В.Жовнірова, Р.В.Дьяченко // Українська культура XXI століття: стан, проблеми, тенденції : матеріали Всеукр. наук.-теорет. конф., 22 грудня 2010 р., м. Київ. Київ : Вид. центр КНУКіМ, 2011. - С. 36-38.

4. Козлов А. И. Пища людей / А. И. Козлов. - Фрязино : ОАО Можайский полигр. комб., 2005. - 268 с.

5. Кравець О. М. Сімейний побут і звичаї українського народу: істор.-етногр. нарис / О. М. Кравець. - Київ : Наук. думка, 1966. - 136 c.

6. Кувеньова О. Ф. Громадський побут українського селянства / О. Ф. Кувеньова. - Київ : Наук. думка, 1966. - 135 с.

7. Ліпєц Ю. В. Розвиток і традиції харчування в українській культурі / Ю. В. Ліпєц // Українська культура ХХІ століття: стан, 
проблеми, тенденції : матеріали Всеукр. наук.-теорет. конф., 22 груд. 2010 р., м. Київ. - Київ : Вид. центр КНУКіМ, 2011. - С. 5155.

8. Маланчук В. А. Побут українців у дослідженнях Володимира Гнатюка / В. А. Маланчук // Народна творчість та етнографія. - 1973. - № 2. - С. 28-34.

9. Наулко В. I. Культура і побут населення України / В. І. Наулко, Л. Ф. Артюх, В. Ф. Горленко [та ін.]. - Київ : Либідь, 1993. -255 c.

10. Ритцер Дж. Макдональдизация общества 5 / Дж. Ритцер ; пер. с англ. А. Лазарева. - Москва : Праксис, 2011. - 590 с.

11. Сохань И. В. Гастрономическая культура глобализирующегося общества - проблемы и перспективы / И. В. Сохань // Дефиниции культуры : сб. трудов участников Bсерос. семинара молодых ученых. - Томск, 2011.- Вып. 9.C. $110-123$.

12. Яценко С. А. Традиційна народна їжа як предмет етнографічного дослідження / С. А. Яценко // Вісн. Житомир. держ. ун-ту ім. І. Франка. - 2006. - Вип. 28. - С. 233-236.

\section{References}

1. Borysenko, M. (2008). The Life of the Urban People of Ukraine in the 30's of the 20th Century. Etnichna istoriia narodiv Yevropy [Ethnic history of the peoples of Europe], issue 24, pp. 12-18. 
2. Volkova, A. (2015). Scientific and ethnographic study of the peculiarities of the technology of Ukrainian national cuisine dishes. Traiektoriia nauky [Trajectory of science], vol. 1(1), pp. 4.1-4.8.

3. Zhovnirova, M., Diachenko, R. (2010). Food and nutrition as an element of traditional Ukrainian household culture. Ukrainska kultura XXI stolittia: stan, problemy, tendentsii : materialy Vseukrainskoi naukovo-teoretychnoi konferentsii [Ukrainian Culture of the 21st Century: State, Problems, Trends: Materials of the AllUkrainian Scientific and Theoretical Conference]. Kyiv, Ukraine, 22 December 2010. Kyiv: Publishing Center of Kyiv National University of Culture and Arts, pp. 36-38.

4. Kozlov, A. (2005). Food of people. Series: Science for all. Available at: http://padabum.com/d.php?id=100732 [Accessed 3 July 2017].

5. Kravets, O. (1996). Family life and customs of the Ukrainian people: historical and ethnographic essay. Kyiv: Naukova dumka, p. 136.

6. Kuveniova, O. (1966). Public life of the Ukrainian peasantry. Kyiv: Naukova dumka, p. 135.

7. Lipets, Y. (2011). The Development and Traditions of Nutrition in Ukrainian Culture. Ukrainska kultura XXI stolittia: stan, problemy, tendentsii: materialy Vseukrainskoi naukovo-teoretychnoi konferentsii [Ukrainian Culture of the 21st Century: State, Problems, Trends: Materials of the All-Ukrainian Scientific and Theoretical Conference]. Kyiv, Ukraine, 22 December 2010. Kyiv: Publishing Center of Kyiv National University of Culture and Arts, pp. 51-55. 
8. Malanchuk, V. (1973). The Life of Ukrainians in the Studies of Volodymyr Hnatiuk. Narodna tvorchist' ta etnohrafiia [Folk art and ethnography], no. 2, pp. 28-34.

9. Naulko, V., Artiukh, L., Horlenko, V. (1993). Culture and Life of the Population of Ukraine. Kyiv: Lybid, p. 255.

10.Rietzer, D. (2011). MacDonaldization of Society. Available at: $<$ http://socioline.ru/files/5/316/ritcer_dzhordzh_makdonaldizaciya_obs hchestva_5_2011.pdf> [Accessed 10July 2017].

11.Sokhan, I. (2011). The gastronomic culture of globalizing society - problems and prospects. Available at: https://www.hse.ru/data/2012/02/29 [Accessed 5 July 2017].

12. Yatsenko, S. (2006). Traditional national food as an object of ethnographic research.

Available at: $<$ http://eprints.zu.edu.ua/2018/1/3.pdf > [Accessed 6 July 2017].

(C) Плюта О. П., 2017 